\title{
Artificial Metalloproteases with Broad Substrate Selectivity Constructed on Polystyrene
}

\author{
Eun Hwa Ko and Junghun Suh ${ }^{*}$ \\ Department of Chemistrv, Seoul National Chiversity. Seoul 151-747. Korea \\ Received.August 31, 2004
}

\begin{abstract}
Although the proteolytic activity of the $\mathrm{Cu}$ (II) complex of cyclen (Cyc) is greatly enlanced upon attaclument to a cross-linked polystyrene (PS), the $\mathrm{Cu}(\mathrm{II}) \mathrm{Cyc}$-containing PS derivatives reported previously hydrolyzed only a very limited number of proteins. The PS-based artificial metalloproteases can overcome thermal, mechanical, and chemical instabilities of natural proteases, but the narrow substrate selectivity of the artificial metalloproteases limits their industrial application. In the present study, artificial metalloproteases exhibiting broad substrate selectivity were synthesized by attaching $\mathrm{Cu}(\mathrm{II}) \mathrm{Cyc}$ to a PS derivative using linkers with various structures in an attempt to facilitate the interaction of various protein substrates with the PS surface. The new artificial metalloproteases hydrolyzed all of the four protein substrates (albumin. myoglobin, $\gamma$ globulin, and lysozyme) examined. manifesting $k_{\text {cal }} / K_{\mathrm{m}}$ values of $28-1500 \mathrm{~h}^{-1} \mathrm{M}^{-1}$ at $50{ }^{\circ} \mathrm{C}$. The improvement in substrate selectivity is attributed to steric and/or polar interaction between the bound protein and the PS surface as well as the hydrophobicity of the microenvironment of the catalytic centers.
\end{abstract}

Key Words : Artificial protease. Metalloprotease. Substrate selectivity. Cu(II)-cyclen, Polystyrene

\section{Introduction}

Designing artificial proteases ${ }^{l}$ is an important subject in the area of bio-related chemistry in view of the importance of proteins in modern biology as well as the high stability ${ }^{2.3}$ of peptide bonds. Hydrolysis of protein mixtures into smaller fragments is carried out in various industries. ${ }^{4.5}$ Proteolysis can be also applied to utilization of agricultural. seafood. and meat byproducts and to improvement of nutritional and functional properties of proteins. ${ }^{4.5}$ Moreover. proteolysis produces peptides with various kinds of bioactivity. ${ }^{(-1)}$ Industrial processes for proteolysis have been perfomed so far with biotic catalysts. Synthetic catalysts hydrolyzing a variety of proteins can lead to alternative processes for proteolysis. To design artificial proteases applicable to protein industries. it is desirable to synthesize immobile catalyssts that hỵdrolyze a variety of proteins at near neutral $\mathrm{pH}$ 's.

Metal ions can play various catalytic roles in peptide hydrolysis acting as Lewis acids. ${ }^{13}$ When various metal complexes were tethered to peptide substrates. highly effective intramolecular catalysis of peptide hyddrolysis was achieved. ${ }^{14.15}$ As intemolecular catalysts for peptide hydrolysis. ${ }^{161 \mathrm{~K}}$ however. metal complexes frequently suffered from low reactivity under physiological conditions. Remarkable improvement of the proteolytic activity of the $\mathrm{Cu}$ (II) complex of cyclen (Cyc: 1) has been achieved when Cu(II)Cyc was attached to a cross-linked polystyrene (PS) ${ }^{\text {jy }}$ Thus. very high proteolytic activity of $\mathbf{2}$ was observed when bovine senum $\gamma$ globulin was used as the substrate. Despite the high proteolytic activity toward $\gamma$ globulin. 2 manifested narrow substrate selectivity having negligible activity toward bovine senum albumin.

\footnotetext{
${ }^{*}$ Corresponding Author. e-mail: jhsuhtogsnu.ac.kr
}

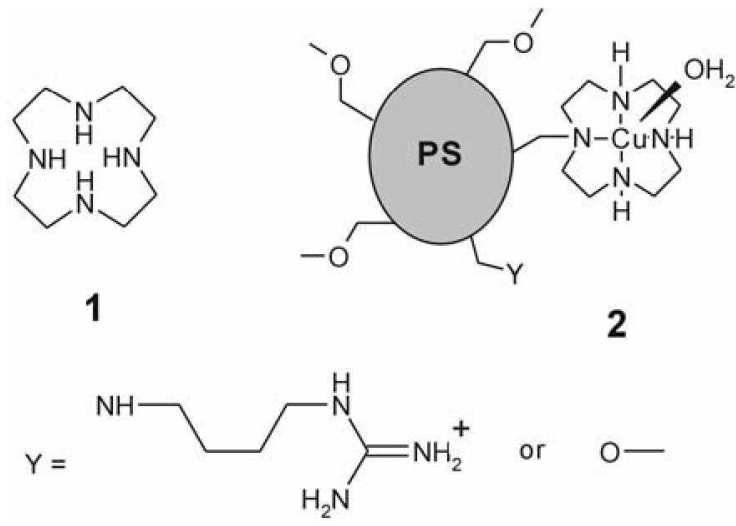

Although the artificial metalloproteases based on PS can overcome limitations of natural proteases such as thenmal. mechanical. and chemical instability. the narrow substrate selectivity of the artificial metalloproteases would limit their industrial applications. In order to use in various types of protein industries. the artificial protease should manifest broad substrate selectivity hydrolyzing almost every protein substrate that the catalyst encounters. In the present study. linkers with various structures were inserted between the PS support and $\mathrm{Cu}(\mathrm{II}) \mathrm{Cyc}$ moiety in an attempt to facilitate the interaction of various protein substrates with the polymer surface

\section{Experimental Section}

Synthesis of the PS-based artificial metalloproteases. Poly'[(aminomethyl) ${ }_{17}$ styrene-co-divinylbenzene] (PAD) a derivative of PS with $17 \%$ of styrene residues aminomethylated (1.5 mimol $\mathrm{NH}_{2}$ per gran polymer) and with $2 \%$ cross-linkage. was purchased from Fluka and employed as 
the solid support of the artificial metalloproteases.

Catalytic module 3 was prepared as reported in the literature ${ }^{-1}$ and 4-7 were prepared according to the synthetic paths summarized in Scheme 1. For $N-\{[4,7,10$-tris(t-butoxy carbonyl)-1.4.7,10-tetraazacyclododecan-1-yl]acetyl $\}$ L-alanine (4): 'H NMR (300 MHz. $\left.\mathrm{CDCl}_{3}\right) \delta 4.55$ (q. $\left.1 \mathrm{H}\right)$. $3.45-3.65$ (br. $8 \mathrm{H}$ ) $3.30-3.45(\mathrm{~m} .4 \mathrm{H}), 3.20$ (s. $2 \mathrm{H}) .2 .60-$ 2.80 (br. $4 \mathrm{H}$ ). $1.35-1.50$ (br. $30 \mathrm{H}$ ): MS (MALDI-TOF) $m z$ $602.95(\mathrm{M}+\mathrm{H})^{+}$, calcd for $\mathrm{C}_{25} \mathrm{H}_{32} \mathrm{~N}_{5} \mathrm{O}_{9} 602.75$. For $N$ $\{[4.7 .10$-tris( $t$-butoxycarbony 1$)-1.4 .7 .10$-tetraazacyclododecan1-yl]acetyl\}-L-phenylalanine (5): ${ }^{\mathrm{l}} \mathrm{H}$ NMR $(300 \mathrm{MHz}$. $\mathrm{CDCl}_{3}$ ): $\delta 7.20-7.30$ (br. $5 \mathrm{H}$ ). 4.83 (q. $1 \mathrm{H}$ ). $3.00-3.60$ (br m. $16 \mathrm{H}$ ). $2.97-2.60$ (br. $4 \mathrm{H}$ ) 1.43 (br. $27 \mathrm{H}$ ): MS (MALDI-TOF) $m=678.99(\mathrm{M}+\mathrm{H})^{+}$. calcd for $\mathrm{C}_{34} \mathrm{H}_{56} \mathrm{~N}_{5} \mathrm{O}_{9} 678.85$. For $N-\alpha-$ acetyl- $N-\varepsilon-\{[4.7,10$-tris( $t$-butoxycarbonyl)-1.4.7.10-tetraazacyclododecan-1-yl]acetỵl\}-L-ly'sine (6): ${ }^{1} \mathrm{H}$ NMR $(300$ $\mathrm{MHz} . \mathrm{CDCl}_{3}$ ) $\delta 4.52$ (s. 1H) $3.10-3.65$ (br. $16 \mathrm{H}$ ). 2.40-2.55 (br. $4 \mathrm{H}$ ), 1.91 (s. 3H), 1.65-1.80 (br s. $4 \mathrm{H}), 1.44$ (m. 27H). $1.20-1.35$ (br s. $2 \mathrm{H}$ ): MS (MALDI-TOF) $m z 701.03$ (M+ $\mathrm{H}^{-}$. calcd for $\mathrm{C}_{33} \mathrm{H}_{6 \times 1} \mathrm{~N}_{6} \mathrm{O}_{1 j} 701.88$. For $N$ - $\{44.7 .10$-tris $(t-$ butoxycarbony 1)-1.4.7.10-tetraazacyclododecan-1-yl]acetyl\}glycylglycine (7): ${ }^{1} \mathrm{H}$ NMR $\left(300 \mathrm{MHz}, \mathrm{CDCl}_{3}\right): \delta 4.02(\mathrm{~d}$ $2 \mathrm{H}$ ). 3.90 (d. $2 \mathrm{H}$ ). 3.55 (br. $8 \mathrm{H}$ ). 3.40 (br. $4 \mathrm{H}$ ). 3.23 (s. 2H) $2.81(\mathrm{~s} .4 \mathrm{H}) .1 .43(\mathrm{~m}, 27 \mathrm{H})$ : MS (MALDI-TOF) $m z 645.99$ $(\mathrm{M}+\mathrm{H})^{-}$. calcd for $\mathrm{C}_{20} \mathrm{H}_{3} \mathrm{~N}_{6} \mathrm{O}_{10} 645.77$.

$\mathrm{PAD}$ was converted to $\mathrm{A}$ by the synthetic route summarized in Scheme 2. The solution $(5 \mathrm{~mL})$ of $3(350 \mathrm{mg})$ mixed with $O$-benzotriazol-1-yl- $N, N, N^{\prime}, N^{\prime}$-tetramethyluraniumhexafluoro phosphate (HBTU) $(250 \mathrm{mg})$. dissopropylethylamine (DIEA) $(0.3 \mathrm{~mL}) . N$-hydroxy benzotriazole (HOBt)
(90 $\mathrm{mg}$ ) in $N, N$-dimethylformamide (DMF) was added to the suspension of PAD ( $3 \mathrm{~g})$ in $30 \mathrm{~mL}$ of DMF. The suspension was degassed for 30 minutes and shaken at $45 \mathrm{rpm}$ and room temperature for 1 day. The product polymer (Ai) was collected by filtration. washed with DMF $(30 \mathrm{~mL} \times 5)$. dichloromethane $(\mathrm{DCM})(30 \mathrm{~mL} \times 5) . \mathrm{MeOH}(30 \mathrm{~mL} \times 5)$. and dried in vacuo. The amino groups of $\mathrm{Ai}$ were acetylated by shaking the polymer $(3 \mathrm{~g})$ with acetic anhydride $\left(\mathrm{Ac}_{2} \mathrm{O}\right)$ $(0.5 \mathrm{~mL})$ and DIEA $(1 \mathrm{~mL})$ dissolved in $30 \mathrm{~mL}$ DMF at room temperature for 1 day. The product polymer (Aii) was collected by filtration. washed with DMF $(30 \mathrm{~mL} \times 5)$. $\mathrm{MeOH}(30 \mathrm{~mL} \times 5)$, and dried in vacuo. Kaiser test ${ }^{2]}$ indicated that the yield of the acetylation step was greater than $99 \%$. Aii $(3 \mathrm{~g})$ was shaken in the mixture of $6 \mathrm{~mL}$ trifluoroacetic acid (TFA) and $24 \mathrm{~mL} \mathrm{DCM}$ at $45 \mathrm{rpm}$ and room temperature for $1 \mathrm{~h}$. The product polymer (Aiii) was collected by filtration, washed with $\mathrm{DCM}(30 \mathrm{~mL} \times 5)$. shaken in $6 \mathrm{~mL}$ DIEA and $24 \mathrm{~mL} \mathrm{DCM}$ at $45 \mathrm{rpm}$ and room temperature for $1 \mathrm{~h}$. washed with DCM $(30 \mathrm{~mL} \times 5)$. $\mathrm{MeOH}$ $(30 \mathrm{~mL} \times 5)$. and dried in vacuo. Aiii $(2.5 \mathrm{~g})$ was suspended in $0.23 \mathrm{M} \mathrm{CuCl}_{2}-2 \mathrm{H}_{2} \mathrm{O}$ solution in DMF $(25 \mathrm{~mL})$. and the resulting mixture was shaken at $45 \mathrm{rpm}$ and room temperature for $l$ day. The product polymer (A) was collected by filtration. washed with DMF $(30 \mathrm{~mL} \times 5)$. water $(30 \mathrm{~mL} \times$ 5), and $\mathrm{MeOH}(30 \mathrm{~mL} \times 5)$. Then $\mathrm{A}$ was suspended again in a $\mathrm{pH} 5$ buffer and the mixture was shaken at $45 \mathrm{rpm}$ and room temperature for 1 day. A was collected by filtration. washed with water $(30 \mathrm{~mL} \times 5)$ and $\mathrm{MeOH}(30 \mathrm{~mL} \times 5)$ and dried in vacuo. PS-based artificial metalloproteases B-E were synthesized by the same procedure by using 4-7<smiles></smiles><smiles>[R]C(N)C(=O)OC</smiles><smiles>COC(=O)C(CCCCN)NC(C)=O</smiles><smiles>COC(=O)C(CCCCNC(=O)CCN1CCN(C(=O)O)CCN(C(=O)O)CCN1)NC(C)=O</smiles>

$6 a$

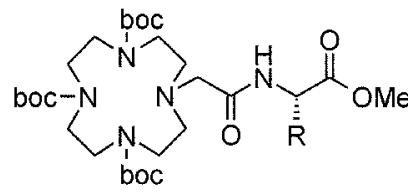

$$
\text { 4a: } \mathrm{R}=\mathrm{CH}_{3}
$$$$
5 \mathrm{a}: \mathrm{R}=\mathrm{CH}_{2} \mathrm{Ph}
$$

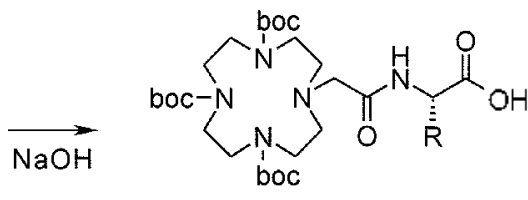

4: $\mathrm{R}=\mathrm{CH}_{3}$ 5: $\mathrm{R}=\mathrm{CH}_{2} \mathrm{Ph}$<smiles>CC(=O)NC(CCCCNC(=O)CN(CCN(CCNO)C(=O)O)CCN(CCN(C(=O)O)C(=O)O)C(=O)O)C(=O)O</smiles>

6<smiles>COC(=O)CNC(=O)CN</smiles>

HBTU<smiles></smiles>

$7 a$

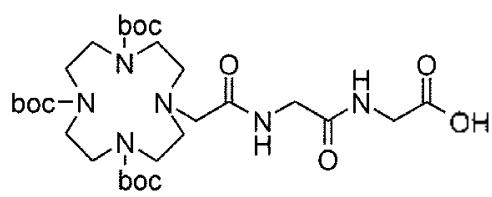

7

Scheme 1. Synthetic routes to various carboxylic acid derivatives containing Cye moieties. 
instead of 3. Contents of the $\mathrm{Cu}(11) \mathrm{Cyc}$ moieties of A-E were determined by measuring the amount of $\mathrm{Cu}$ (II) ion bound to the PS. The cataly'st $\left(20 \mathrm{mg}\right.$ ) was suspended in $1 \mathrm{~N} \mathrm{HNO}_{3}$ solution $(10 \mathrm{~mL})$. shaken at the speed of $100 \mathrm{rpm}$ for a day at room temperature. separated by filtration. and washed with 1 $\mathrm{NHNO}_{3}(5 \mathrm{~mL} \times 2)$. This process was repeated twice. The concentrations of $\mathrm{Cu}(\mathrm{II})$ ion in the filtrates were detemined by Inductively Coupled Plasma-Atomic Emission Spectroscopy (ICP-AES). The contents of the $\mathrm{Cu}$ (II)Cyc moieties of the artificial metalloproteases thus determined are $1.4 \%$ (relative to the content of styrene moieties) for A. $1.4 \%$ for B. $1.5 \%$ for C. $1.2 \%$ for D. and $1.4 \%$ for $E$.

Measurements. In kinetic measurements. the shaking speed and temperature were controlled with a VORTEMP manufactured by Labnet. $\mathrm{pH}$ measurements were carried out with a Dongwoo Medical DP-880 pH/Ion meter. The degree of cleavage of proteins was measured by sodium dodecyl sulfate polyacrylamide gel electrophoresis (SDS-PAGE) $=$ with a Mighty Small II SE 250 model. Densities of the electrophoretic bands were analyzed with a AlphaImager ${ }^{\mathrm{TM}}$ 2200 model and a AlphaEase ${ }^{\mathrm{TM}}$ model. Distilled and deionized water was used for preparation of buffer solutions. Buffers $(0.05 \mathrm{M})$ used for the kinetic measurements were sodium acetate ( $\mathrm{pH} \mathrm{5.0)}$, 4-morpholineethanesulfonic acid (pH $6.0,6.5), \quad N$-2-hy'droxyethylpiperazine- $N^{\prime}$-ethansulfonate $(\mathrm{pH} 7.0,7.5 .8 .0), \mathrm{N}$-tris(hydroxymethyl)methyl-3aminopropanesulfonate $(\mathrm{pH} 8.5)$, boric acid $(\mathrm{pH} 9.0 .9 .5$. 10.0 ) and 3-(cyclohexylamino)-1-propanolsulfonate $(\mathrm{pH}$ 10.5). All of the buffer solutions were filtered with a 0.45 $u \mathrm{~m}$ Millipore microfilter and autoclaved before use in the kinetic measurements. Protein substrates (bovine serum albumin. horse skeletal muscle my oglobin. chicken egg white lysoz̧'me and bovine senum $\gamma$ globulin) were purchased from Sigma and used without further purification. The PSbased catalyst $(20 \mathrm{mg})$ was suspended in the buffer solution $(0.90 \mathrm{~mL})$ and swollen for $1 \mathrm{~h}$ prior to kinetic measurement. A portion $(0.10 \mathrm{~mL})$ of the substrate stock solution was added to the heterogeneous mixture and the resulting mixture was shaken at the speed of $1000 \mathrm{rpm}$ and at $50^{\circ} \mathrm{C}$. The mixture was centrifuged at various intervals and the upper layers $(20 \mu \mathrm{L})$ of the mixture were collected and subjected to analysis by SDS-PAGE.

\section{Results}

Various linkers were inserted between the phenyl group of the styrene residue of $\mathrm{PS}$ and $\mathrm{Cu}(\mathrm{II}) \mathrm{Cyc}$ to alter the microenvirouments of the catalytic $\mathrm{Cu}(\mathrm{II}) \mathrm{Cyc}$ moieties. For this purpose. several carbosylic acids containing a protected form of $\mathrm{Cyc}$ were synthesized according to the synthetic routes summarized in Scheme 1. PAD. a PS derivative with $17 \%$ of styrene residues aminomethylated and with $2 \%$ cross-linkage. was employed as the solid support of the artificial proteases. The catalyst was syinthesized by coupling of a Cyc-containing carboxylic acid (3-7) with PAD . acetylation of the excess amino groups of PAD. deprotection of the Cyc moiety and insertion of Cu(II) ion as summarized in Scheme 2. The structures of the PS-based artificial metalloproteases prepared in this study are indicated by A-E (Schemes 2 and 3). Contents of $\mathrm{Cu}(11) \mathrm{Cyc}$ moieties in A-E were $1.2-1.5 \%$ (relative to the content of styrene moieties).

Proteolytic activity of A-E was tested by using albumin (M.W. $66 \mathrm{kDa}$ ), myoglobin (M.W. $17 \mathrm{kDa}$ ), $\gamma$ globulin (M.W. $150 \mathrm{kDa}$ ), and lysozyme (M.W. $14 \mathrm{kDa}$ ) as the substrates. While the buffer solution containing each substrate

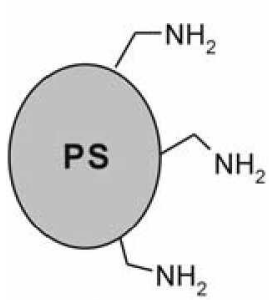

PAD

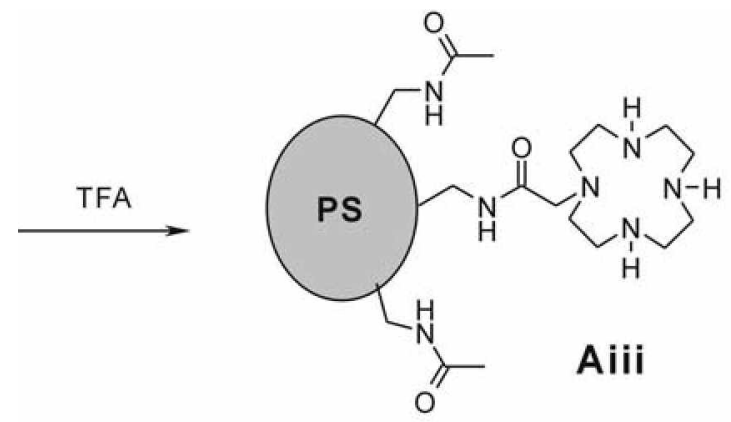

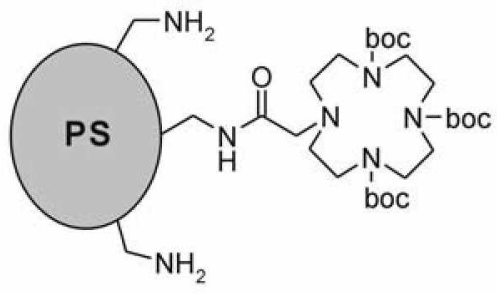

$\mathrm{Ai}$
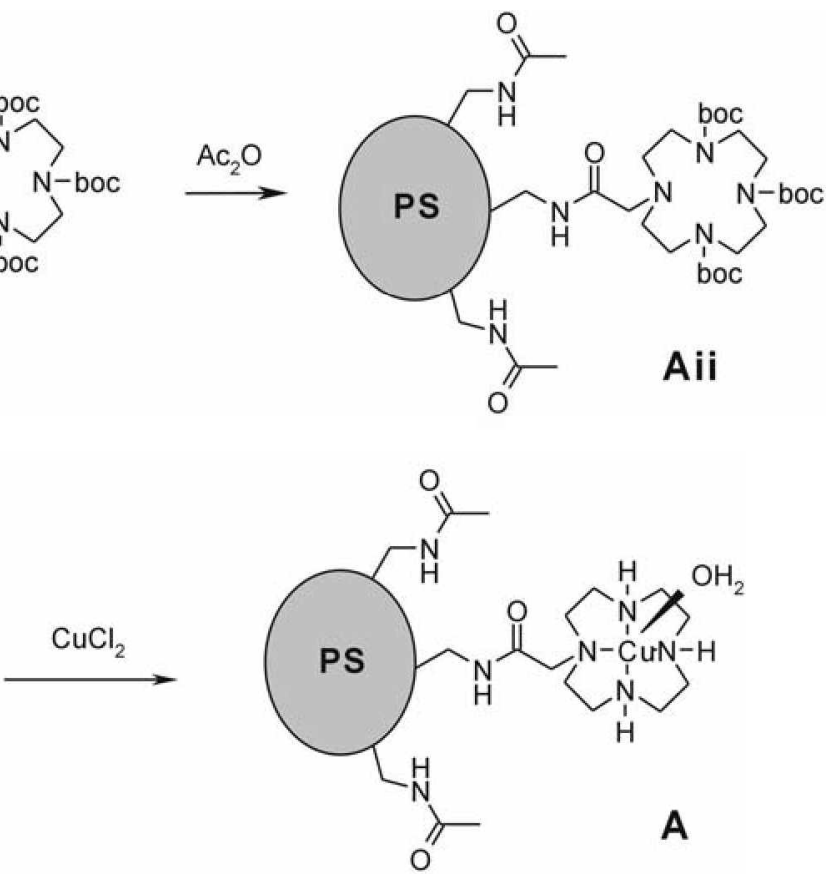

Scheme 2. Synthetic route to catalyst A. 


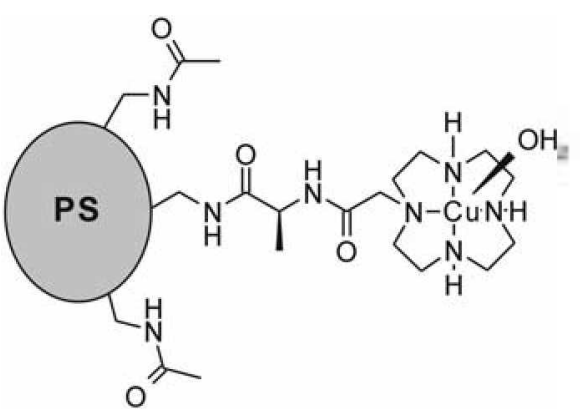

B

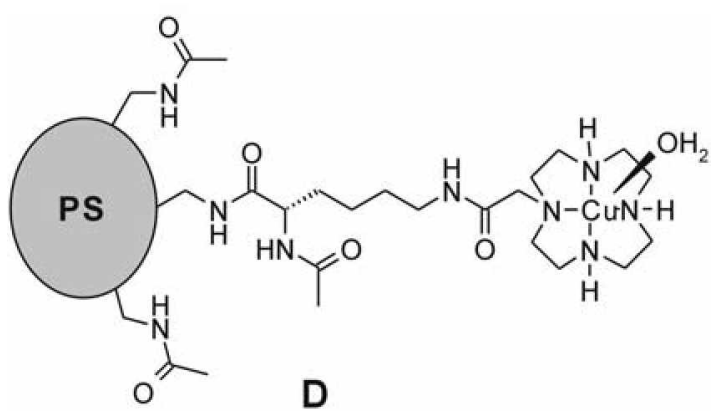<smiles>CC(=O)NCC1CCCCCCCCC(CNC(C)=O)CC(CNC(=O)C(Cc2ccccc2)NC(=O)CN2CCN3CCN4CCN(CC3)C42CO)CC1</smiles>

C

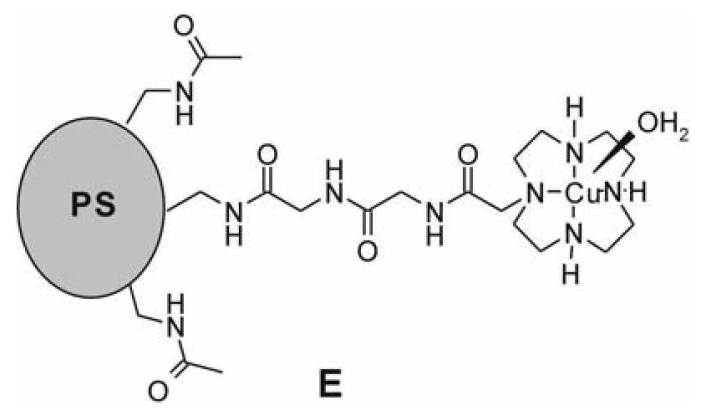

Scheme 3. Structures of catalysts B-E synthesized by the route summarized in Scheme 2.

was shaken in the presence of the PS derivative, rates for cleavage of the protein were measured by following disappearance of the parent band in the gel electrophoresis (SDS-PAGE). Typical results of electrophoresis are illustrated in Figure 1. That the disappearance of the electrophoretic band of each protein was not due to the adsorption onto the insoluble support was confinmed by measuring the total amino acid content ( $70-100 \%$ yield) of the product solution separated from the insoluble catalyst by filtration. ${ }^{23}$ The rate

$$
\begin{array}{llllllll}
0 \mathrm{~h} & 0.25 \mathrm{~h} & 0.5 \mathrm{~h} & 1 \mathrm{~h} & 1.5 \mathrm{~h} & 2 \mathrm{~h} & 3 \mathrm{~h} & 5 \mathrm{~h}
\end{array}
$$

Figure 1. Results of SDS-PAGE performed on albumin $\left(S_{0}=3.01\right.$ $\left.\times 10^{-5} \mathrm{M}\right)$ incubated with $\mathrm{B}\left(C_{0}=1.27 \mathrm{~mm}\right)$ at $\mathrm{pH} 9.0$ and $50^{\circ} \mathrm{C}$.

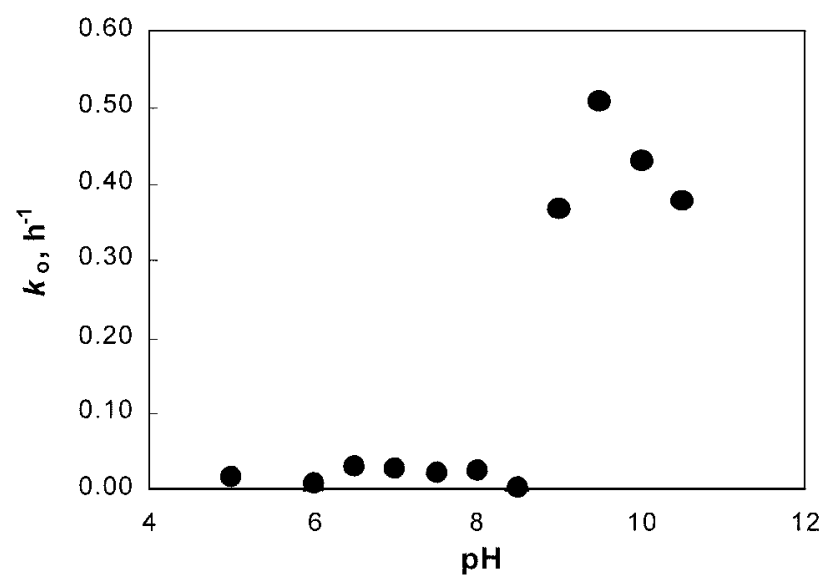

Figure 2. Values of $k_{0}$ measured for cleavage of albumin by $B$ at 50 ${ }^{\circ} \mathrm{C}$ and various $\mathrm{pH}$ 's $\left(\mathrm{S}_{\mathrm{o}}=3.01 \times 10^{-5} \mathrm{M}, \mathrm{C}_{0}=1.27 \mathrm{mM}\right)$. of protein cleavage was measured by monitoring the decrease in the intensity of the electrophoretic bands corresponding to the protein substrates. ${ }^{19.20}$ The values of pseudo-first-order kinetic constant $\left(k_{0}\right)$ were measured at the shaking speed of $1000 \mathrm{rpm}$ since $k_{\circ}$ reached the plateau value at the shaking speed exceeding $800 \mathrm{rpm}$. For $\gamma$ globulin. which contains two types of chains. the kinetic data were collected for the heavy chain although the light chain was also cleaved.

The $k_{0}$ values for degradation of each protein substrate by A-E were measured at several $\mathrm{pH}$ 's $(\mathrm{pH} 5.0-10.5)$ and $50^{\circ} \mathrm{C}$ by fixing $S_{0}$ (the initially added concentration of the substrate) and $C_{0}$ (the initially added concentration of the cataly'st: calculated by assuming that the catalyst is dissolved in the buffer solution) for each catalyst. as exemplified by

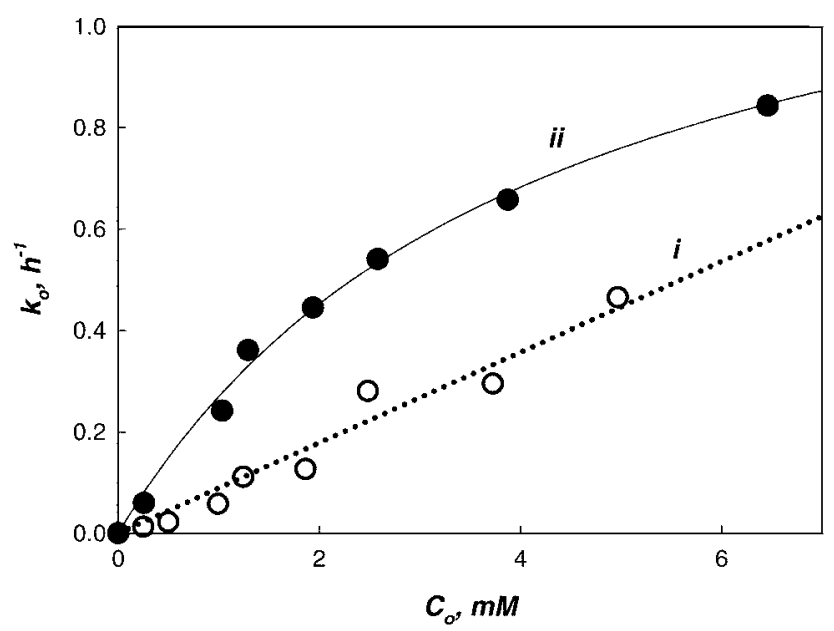

Figure 3. Dependence of $k_{0}$ on $C_{\text {i }}$ for cleavage of lysozyme by $\mathrm{A}$ $(\therefore$ : i) at $\mathrm{pH} 9.5$ and by $\mathrm{E}(\bullet:$ ii) at $\mathrm{pH} 100$. 
Table 1. Values of kinetic parameters for cleavage of proten substrates by catalysts A-E $\mathrm{E}^{a, b}$

\begin{tabular}{|c|c|c|c|c|c|}
\hline & & albumint & myoglobin & $\gamma$-globulin & lysozyme \\
\hline \multirow[t]{3}{*}{$\mathbf{A}$} & $k_{\mathrm{sat}}$ & - & - & 1.1 & - \\
\hline & $K_{\mathrm{m}}$ & - & - & 4.9 & - \\
\hline & $k_{\mathrm{cat}} / K_{\mathrm{m}}$ & $28(9.5)$ & $50(10.0)$ & $220(10.0)$ & $89(9.5)$ \\
\hline \multirow[t]{3}{*}{ B } & $k_{\text {cat }}$ & 1.2 & 4.9 & - & 1.6 \\
\hline & $K_{\mathrm{m}}$ & 2.6 & 3.3 & - & 3.0 \\
\hline & $k_{\mathrm{cat}} / K_{\mathrm{m}}$ & $450(10.0)$ & $1500(9.0)$ & $570(9.5)$ & $520(9.0)$ \\
\hline \multirow[t]{3}{*}{ C } & $k_{\text {cat }}$ & 1.0 & - & 5.4 & 1.4 \\
\hline & $K_{\mathrm{m}}$ & 1.3 & - & 5.6 & 2.1 \\
\hline & $k_{\mathrm{cat}} / K_{\mathrm{m}}$ & $770(10.0)$ & $190(9.5)$ & $960(10.0)$ & $630(9.0)$ \\
\hline \multirow[t]{3}{*}{ D } & $k_{\text {cat }}$ & 2.0 & - & - & 2.2 \\
\hline & $K_{\mathrm{m}}$ & 5.0 & - & - & 4.9 \\
\hline & $k_{c a t} / K_{\mathrm{m}}$ & $410(10.0)$ & $200(9.5)$ & $530(10.0)$ & $440(9.0)$ \\
\hline \multirow[t]{3}{*}{$\mathbf{E}$} & $k_{\text {cat }}$ & 3.2 & 1.1 & 2.7 & 1.4 \\
\hline & $K_{\mathrm{m}}$ & 7.5 & 2.6 & 3.5 & 4.2 \\
\hline & $k_{\mathrm{cat}} / K_{\mathrm{m}}$ & $420(10.0)$ & $410(9.5)$ & $770(9.5)$ & $330(10.0)$ \\
\hline
\end{tabular}

"Measured at 50 ${ }^{\circ} \mathrm{C}$ and the optimum $\mathrm{pH}$ in the presence of $0.05 \mathrm{M}$ bufferer. Units are $\mathrm{h}^{-1}$ for $k_{\text {call }} \mathrm{mM}$ for $K_{\mathrm{mr}}^{-}$and $\mathrm{h}^{-1} \mathrm{M}^{-1}$ for $k_{\text {carl }} K_{\mathrm{ml}}$ optimum $\mathrm{pH}$ 's are indicated in parentheses.

the results illustrated in Figure 2

At the optimum $\mathrm{pH}$ thus selected. the dependence of $k_{0}$ on $C_{0}$ was measured under the conditions of $C_{0} \gg S_{0}$. Either a saturation curve or a linear line was observed for the plot of $k_{0}$ against $C_{0}$ as illustrated in Figure 3. The kinetic data were analyzed in terms of Michaelis-Menten scheme (eq. 1). ${ }^{20}$ Under the conditions of $C_{0} \approx[C], k_{0}$ is expressed as eq. (2). predicting saturation kinetic behavior for the plot of $k_{0}$ against $C_{0}$. When $K_{\mathrm{m}} \gg C_{0}$. however. $k_{0}$ is proportional to $C_{0}$ (eq. 3), with the proportionality constant being equal to $k_{\text {cat }} /$ $K_{\mathrm{m}}$. For the reactions manifesting saturation kinetic behavior. the values of $k_{\text {cat }} . K_{\mathrm{m}}$. and $k_{\text {cat }} / K_{\mathrm{m}}$ were estimated by analyzing the dependence of $k_{0}$ on $C_{0}$ with a nonlinear regression program. For the reactions manifesting linear kinetic behavior. the values of $k_{\text {cat }} / K_{\mathrm{m}}$ were taken as the proportionality constant. The values of kinetic parameters thus obtained are summarized in Table 1. For the reactions with no values given for $k_{\text {cat }}$ and $K_{\mathrm{m}}$ in Table 1, the linear kinetic behavior indicates that $K_{\mathrm{m}}$ is greater than $10 \mathrm{mM}$

$$
\begin{gathered}
C+S \frac{k_{1}}{k_{-1}} C S \stackrel{k_{\imath}}{\rightarrow} C+P \\
k_{0}=k_{\text {cat }} C_{\mathrm{c}} /\left(K_{\mathrm{m}}+C_{0}\right) \\
\text { where } \quad k_{\text {cat }}=k_{2} \text { and } K_{\mathrm{m}}=\left(k_{-1}+k_{2}\right) / k_{1} \\
k_{0}=k_{\mathrm{cat}} C_{0} / K_{\mathrm{m}} \text { when } K_{\mathrm{m}} \gg C_{0}
\end{gathered}
$$

The values of $k_{\text {cal }} / K_{\mathrm{m}}$ are estimated for all of the proteolytic reactions examined. Among the kinetic parameters of the Michaelis-Menten scheme. $k_{\text {cat }} / K_{\text {m }}$ stands for the reactivity between the cataly'st and the substrate and is regarded as the

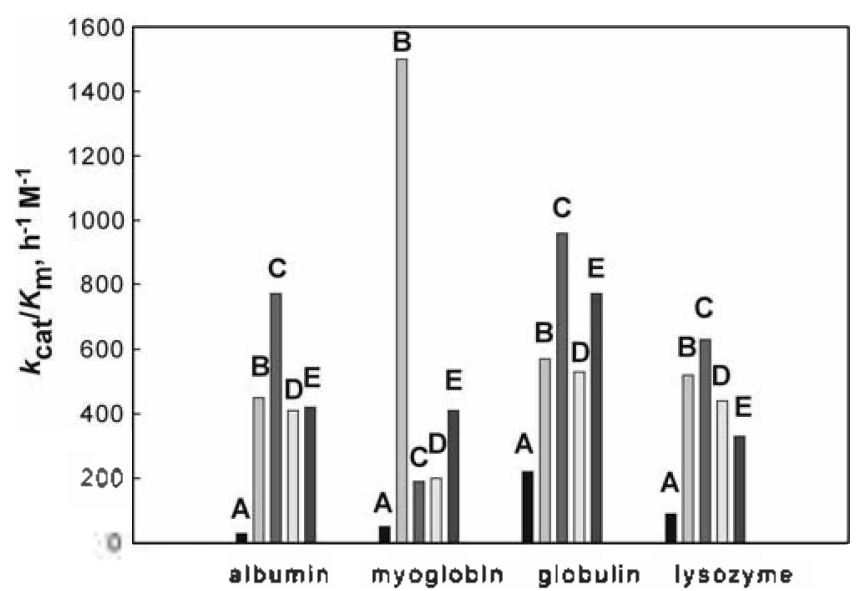

Figure 4. Values of $k_{\text {and }} / K_{m}$ for cleavage of protein substrates by catalysts A-E summarized in Table 1 .

typical parameter to represent enzyme activity. The values of $k_{\mathrm{cat}} / K_{\mathrm{m}}$ measured for the proteolytic action of A-E at the respective optimum $\mathrm{pH}$ 's are compared in Figure 4. The relative reactivity of artificial metalloproteases represented by $k_{\text {cat }} / K_{\mathrm{m}}$ reflects both the ability of the cataly'sts to form productive complexes with substrates and the reactivity of the catalyst-substrate complexes.

\section{Discussion}

It is well established that the cleavage of proteins by Cu(II)Cyc attached to PS occurs by hydrolysis of the polypeptide backbones. ${ }^{19.210}$ In view of the catalytic roles ${ }^{13}$ of metal ions acting as Lewis acid catalysts in peptide hydroly'sis. possible mechanisms for the $\mathrm{Cu}$ (II)Cyc-catalyzed proteoly sis are indicated as $\mathbf{8}$ and $\mathbf{9}$. Here, the $\mathrm{Cu}$ (II) center can activate the carbonyl group of the scissile peptide bond by binding at the carbonyl oxygen. $\mathrm{Cu}(\mathrm{II})$-bound hydroxide ion can act as a potent nucleophile. Those catalytic roles can take place cooperatively as indicated by 9 .

The Cu(II) complex of $\mathrm{Cyc}$ itself has negligible proteolytic activity. The proteolytic activity of $\mathrm{Cu}$ (II)Cyc is remarkably activated however, when it is attached to a PS derivative. ${ }^{\text {ig }}$ A possible explanation for the effect of PS is that dimerization of the $\mathrm{Cu}$ (II) complex through formation of hydroxo or oxo bridge is prevented when the metal center is fixed on a polymer surface. Upon dimerization. the metal center would not be able to interact with peptide bonds of the substrate proteins. Deactivation of $\mathrm{Cu}(\mathrm{II}) \mathrm{Cy}$ c by dimer formation is not likely however. since no evidence has been reported for dimerization of related complexes ( $\mathrm{Zn}$ (II)Cyc and $\mathrm{Co}(\mathrm{III}) \mathrm{Cyc}^{24.25}$ although their solution behavior has been thoroughly investigated.

Instead. the effects of the PS support can be related to the unique microenvironments created on the surface of the PS which can enhance the intrinsic reactivity of the metal center. Rates of many organic reactions are sensitive to the nature of the reaction media. In both 8 and 9 . the transition state of the rate-determining step has considerably lower 

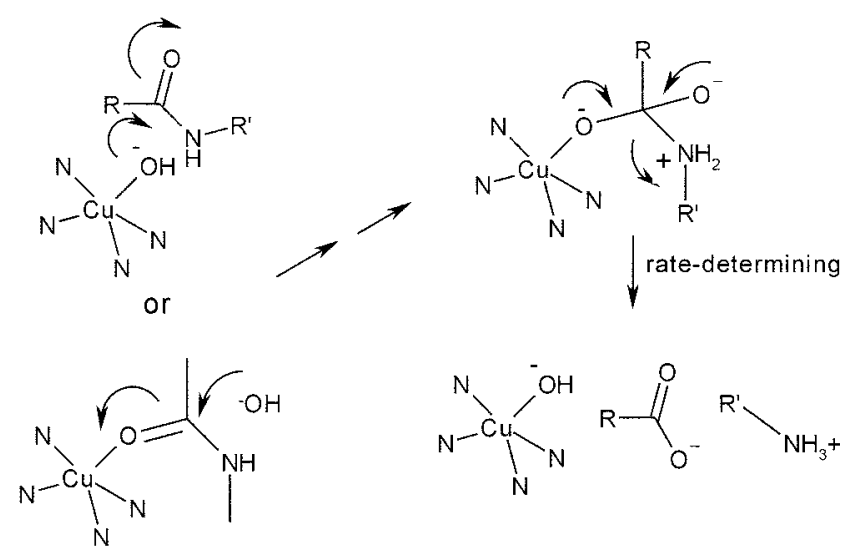

8

charge density than the corresponding ground state. which can lead to remarkable acceleration ${ }^{-6}$ simply by lowering polarity of the medium. The microenviromment of the Cu(II)Cyc moiety attached to PS would be affected by the styrene phenyl groups of the PS backbone, organic pendants attached to the polymer. and water molecules from the solvent. It has been suggested that the nonpolar microenvironment is important for the catalytic activity of the PSbound metal complexes of Cyc in the cleavage of not only proteins but also DNAs. ${ }^{\text {] }}$

In order for the PS-based Cu(II)Cyc to cleave a protein. it is prerequisite that the protein molecule is complexed to the PS surface. Some factors would affect the ability of the protein to bind to the polymer. First. steric strain would be imposed by the PS surface when a peptide bond of the protein interacts with the $\mathrm{Cu}$ (II)Cyc center. Second. the structure of the polymer surface would affect the polar and the nonpolar interactions between the protein and the catalyst.

As illustrated in Figure 4. A-E hyddrolyze all of the protein substrates examined in the present study. exhibiting wide substrate selectivity. This stands in contrast to 2 . which manifested narrow substrate selectivity as mentioned above. Among A-E A has the lowest proteolytic activity

The difference in the reactivity of the catalysts may be related to the different microenvironments of the catalytic center. For 2 most of the styrene residues of the PS support contained chloromethyl groups which were mostly converted to ether groups. On the other hand. only $17 \%$ of the styrene residues of the PS support of A-E contained aminomethyl groups which were mostly converted to acetamide groups. Thus. the microdomains on the PS surface are considerably different for 2 and A-E. The polar or the hydrophobic interaction between the functional groups located on the protein surface and those on the PS surface would play important roles in complexation of the protein substrate to the PS surface.

The Cu(II)Cy'c catalytic center of 2 is attached to the styrene residue of PS by using the methylene group as the linker. Thus. A-E have longer linkers than 2. When the protein substrate interacts with the $\mathrm{Cu}(\mathrm{II}) \mathrm{Cyc}$ center. the

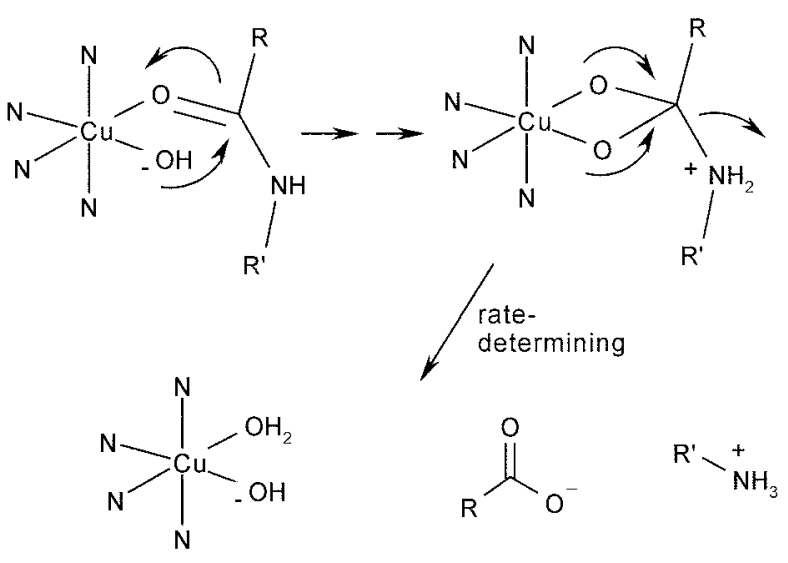

9

protein can suffer from steric strain with the PS surface when a shorter linker is used. Length of the spacer would affect not only the steric strain but also the interaction between the functional groups located on the protein surface and those on the PS backbone. In addition, the polarity of microenvironment and. consequently, the proteolytic reactivity of the $\mathrm{Cu}(\mathrm{II}) \mathrm{Cyc}$ center would be affected by the length and the structure of the linker. The narrow substrate selectivity of 2 in marked contrast with A-E. therefore. can be related to its short linker.

Rate data for catalytic reactions that involve formation of the catalyst-substrate complexes can be analyzed by the Michaelis-Menten scheme. As demonstrated by many enzy'matic reactions. Michaelis-Menten parameters $k_{\text {cat }} K_{\mathrm{m} \text {. }}$ and $k_{\mathrm{cal}} / K_{\mathrm{m}}$ are composed of several rate constants and mechanistic information derived from those kinetic parameters is generally very limited. Among the parameters. $k_{c a t} / K_{\mathrm{m}}$ best stands for the reactivity of the cataly st. The data summarized in Figure 4 indicate that $\mathrm{A}$ has the lowest proteolytic activity among A-E for all of the protein substrates examined in the present study: For albumin, zglobulin. and lysozyme. C manifests the highest proteolytic activity among the PSbased catalỵsts. For mỵoglobin. B has uniquely high proteolytic activity. The lowest activity manifested by $\mathrm{A}$ may be related to the shortest linker connecting the $\mathrm{Cu}$ (II)Cyc moiety to PS. Although the linker is shorter for $\mathrm{C}$ than for D or E. better proteolytic activity is observed with $C$ for albumin. $\gamma$ globulin, and ly sozyme. This implicates that the lengthening the linker beyond an optimum size does not improve the activity. The high catalytic activity of $\mathrm{C}$ may be also attributed to the phenyl side chain attached to the linker which may keep the microenvironment more hydrophobic. The much higher activity of $\mathrm{B}$ compared with $\mathrm{C}$ for the cleavage of myoglobin suggests that the phenyl ring of $\mathrm{C}$ may imposed additional steric strain in the complex formed with myoglobin.

Although longer linkers with more complex structures have not been tested the results of the present study indicate that the substrate selectivity and the proteolytic activity of the artificial metalloproteases based on the $\mathrm{Cu}$ (II)Cyccontaining PS can be controlled by variation in the structure 
of the linker connecting $\mathrm{Cu}$ (II)Cyc to PS and the functional groups covering the PS surface.

\section{Conclusions}

In the previous study. ${ }^{\text {t5 }}$ the first artificial metalloproteases operating under physiological conditions were synthesized by enhancing the proteolytic activity of $\mathrm{Cu}$ (II)Cre through attaclument to PS. Both the PS backbone and the Cu(II)Cyc moiety are responsible for the proteolytic activity of the $\mathrm{Cu}(\mathrm{II})$ Cyc-containing PS derivatives. The proteolytic activity is further enhanced by changing the structure of the linkers connecting $\mathrm{Cu}$ (II)Cyc and PS in this work. If the artificial metalloproteases are further improved to exhibit amino acid selectivity with regard to cleavage sites. they may be able to replace natural proteases in various types of industrial applications.

Acknowledgments. This work was supported by Korea Research Foundation Grant (KRF 2001-015-DS0029).

\section{References}

1. Sul. J. Ace. Chem. Res. 2003. 36. 562

2. Radzicka. A.: Wolfenden. R. J. Am Chem. Soc 1996. 118 . 6105 .

3. Smith, R. S: Hansen, D. E. J. Am. Chem. Soc. 1998. 120.8910

4. Ward. O. P. In Comprehensive Biotechmology: Moo-Young. M. Ed.: Pergamon: Oxford. 1985: Vol. 3. pp 789-818.

5. Tramper. J. In .Applied Biocatah sis: Cabral. J. M. S. Best. D. Boross. L.. Tramper. J.. Eds.: Harwood Academic Publishers: Chur. 1994: pp l-46.
6. Brantl, V: Pfeiffer, A.: Herz, A.; Henschen. A.: Louttspeich, F. Peptides 1982. 3. 793.

7. Meisel. H. FEBS Lett. 1986. 196. 223.

8. Saito. H.: Miyakawa. H.: Tamura. Y.: Shimamura. S.: Tomita. M. J. Dain Sci. 1991, 74. 3724.

9. Fiat. A.-M.: Migliore-Samour. D.: Jolles, P.: Drouet. L.: Sollier, C. B. D. Caen, J. J. Dainy Sci. 1993, 76. 301.

10. Kayser. H.: Meisel. H. FEBS Lett. 1996. 383. 18.

11. Matar. C.: Nadathur. S. S.: Bakalinski. A. T.: Goulet. T. J. Dairy Sci. 1997. 80. 1965.

12. Nakagomi. K.: Yamada, R.; Ebisu. H.: Sadakane. Y.: Akizawa. T.: Tanimura, T. FEBS Lett. $\mathbf{2 0 0 0}, \mathbf{1 6 7 , 2 3 5 .}$

13. Suh. J. Acc. Chom. Res. 1992, 25, 273.

14. Sutton. P. A.: Buckingham. D. A. Acc. Chent. Res. 1987. 20.357.

15. Rana. T. M.: Meares. C. F. Proc. Natl Acad Sci. LS. 1991. 88. 10578

16. Chin. J.: Jubian. V:; Mrejen, K. J. Chem. Soc., Chem. Commun. 1990. 1326.

17. Zhu. L.: Qin. L.; Parac, T. N.: Kostic, N. M. J. Am. Chem. Soc. 1994. 116.5218 .

18. Hegg. E. L.: Burstyt1. J. N. J. Ant. Chent. Soc. 1995. 117. 7015.

19. Jang. B.-B.: Lee. K. P: Min. D. H.: Suh. J. J. Am. Chem. Soc. 1998. 120,12008

20. Yoo, C. E; Chae, P.: Kim, J. E.; Jeong, E. J; Suh. J. J. Am Chem Soc. 2003, 125, 14580 .

21. Sarit1. V. K.: Kent. S. B. H: Tam. T. P.: Merrifield. R. B. Anal. Bichem. 1981. 117. 147.

22. Hames. B. D. In Gel Electrophoresis of Proteins: Hames. B. D. Rickwood. D.. Eds: IRL Press: New: York, 1990: Chap. 1.

23. Suh. J.: Oh, S. J. Org. Chem $\mathbf{2 0 0 0}, 65.7534$.

24. Koike. T; Takamura. M.: Kimura. E. d. Am. Chem. Soc. 1994. 116,8443 .

25. Clarkson. A. T.: Buckingham. D. A.: Rogers. A. T.: Blackman. A G.: Clark. C. R. horg. Chem. 2000. 39. 4769.

26. Carroll. F. A. Perspectives on Structure and Hechonisn in Organic Chemison. Brooks Cole: Pacifie Grove. 1998; 329. 